\title{
TURYSTYKA TATRZAŃSKA I ETOS TURYSTY W DOBIE NOWOCZESNOŚCI
}

\section{ETOS TATRZAŃSKI - OGÓLNA CHARAKTERYSTYKA}

Góry są szczególnym rodzajem środowiska naturalnego, budzą w ludziach ciekawość, zachwyt, ale też obawy. Wyzwalają chęć pokonania wysokości, zapanowania nad tym, co człowieka przerasta, zarówno w fizycznym, jak i metaforycznym sensie, zdobycia szczytu. Krajobraz wysokogórski w górach typu alpejskiego, tak odrębny od nizinnych pejzaży, w otoczeniu których znakomita większość ludzi żyje na co dzień, jest kolejnym bodźcem popychającym ich do turystyki górskiej.

Tatry są w świadomości Polaków miejscem wręcz symbolicznym, co przez wiele lat objawiało się wyjątkowym szacunkiem żywionym wobec nich. Powodem tego swego rodzaju uniżonego nastawienia była nie tylko groza i pewna tajemnica otaczająca Tatry, odczuwana zwłaszcza przez ich pierwszych eksploratorów (zarówno górali, jak i przybyszów z innych zakątków Polski i Europy), ale także swoista kultura, jaka z czasem wytworzyła się wokół nich, zwłaszcza dzięki twórcom okresu romantycznego i młodopolskiego. Niecodzienny krajobraz stanowił bowiem inspirację dla utworów malarskich, literackich, muzycznych, które trwale ukształtowały wizerunek Tatr i sprawiły, że zostały one, wraz z folklorem góralskim, uznane za emblemat polskości.

Ze względu na powyższe uwarunkowania oraz specyfikę zwiedzania gór można mówić o wytworzeniu się etosu turysty tatrzańskiego. Wyraz ,etos” pochodzi z greki, w której, zależnie od pisowni, oznacza albo obyczaj, zwyczaj lub przyzwyczajenie nabyte poprzez ćwiczenie ("̌s $\theta o \varsigma)$, albo usposobienie, charakter, sposób zachowywania się lub bycia $(\tilde{\dot{\eta}} \theta o \varsigma)^{1}$. Na potoczną definicje terminu składają się oba rozumienia - etos to „,wartości, obyczaje, normy, wzory postępowania składające się na styl życia i charakter danej grupy ludzi określające jej odrębność" ${ }^{2}$. Refleksja socjologiczna ujmuje etos z dwóch przeciwstawnych perspektyw: statycznej arystotelesowskiej, w której etos jest wyrazem trwałego, zakorzenionego i przekazywanego podczas międzypokoleniowej transmisji kultury sposobem życia, i dynamicznej weberowskiej, gdzie etos może być przyczyną zmiany społecznej (czego sam Max Weber dowodzi w rozprawie Etyka protestancka a duch kapitalizmu ${ }^{3}$ ). Natomiast

\footnotetext{
${ }^{1}$ T. Szawiel, Etos, w: Z. Bokszański, A. Kojder (red.), Encyklopedia socjologii, t.1, Oficyna Naukowa, Warszawa 1998, s. 202.

${ }^{2}$ Stownik wyrazów obcych. Wydanie nowe, Wydawnictwo Naukowe PWN, Warszawa 1995.

${ }^{3}$ M. Weber, Etyka protestancka a duch kapitalizmu, Tekst, Lublin 1994.
} 
według Marii Ossowskiej etos jest „stylem życia jakiejś społeczności, ogólną orientacją jakiejś kultury, przyjęta przez nią hierarchia wartości, bądź formułowaną explicite, bądź dającą się odczytać z ludzkich zachowań"4. Dekonstrukcję etosu tatrzańskiego należy rozpocząć od wyodrębnienia jego części składowych i wskaźników. W odniesieniu do turystów tatrzańskich na ów zespół wartości składają się:

- cele i motywacje kierujące przyjeżdżającymi w Tatry,

- działania instytucjonalne,

- wiedza dotycząca gór i ich znajomość,

- przygotowanie fizyczne i psychiczne do uprawiania turystyki górskiej,

- przygotowanie techniczne i organizacyjne,

- zachowania piętnowane,

- zachowania aprobowane i pożądane.

Wszystkie wymienione elementy składające się następnie na etos konotuja, w zależności od okresu, nieco odmienne treści, zwłaszcza w aspekcie behawioralnym, który zmienia się w stosunkowo najszybszym tempie i którego metamorfozy sa najbardziej widoczne. Oczywiście pewne treści - poglądy, sposoby zachowania, wymagana wiedza pozostają niezmienne, choć zmienia się forma ich uzewnętrzniania. Ale w etosie najważniejsze są właśnie przymioty duchowe, skłonności moralne, będące siłą napędową działań, a one, jak naucza szkoła Annales, ulegają zmianom w procesach długiego trwania, czyli w bardzo długich przedziałach czasowych. Historię polskiej turystyki tatrzańskiej podzielić można na cztery etapy:

- okres pierwszy - XIX w., czyli zalążki właściwej turystycznej eksploracji Tatr;

- okres drugi - od początku XX w. do 1945 r. (w praktyce do zakończenia drugiej wojny światowej);

- okres trzeci - okres Polski Ludowej (od 1945 r. do 1989 r.);

- okres czwarty - od upadku ustroju socjalistycznego (1989 r.) do dziś (turystyka III Rzeczpospolitej).

Stosunkowo najsłabiej poznany jest okres ostatnich dwudziestu lat, dlatego uzasadnione było, zważywszy na ciagłą istotność Tatr w polskiej świadomości zbiorowej, zbadanie form oraz zmian etosu, a także w szerszej perspektywie scharakteryzowanie całokształtu współczesnej turystki tatrzańskiej. Taki cel miały badania terenowe prowadzone przeze mnie w 2009 r. na obszarze Tatrzańskiego Parku Narodowego i w Zakopanem, których uzupełnieniem były wywiady z zadeklarowanymi turystami przeprowadzone w Poznaniu. Zebrany materiał empiryczny umożliwił prześledzenie, czy i jak zdaniem respondentów zmieniły się sposoby uprawiania turystyki górskiej w perspektywie zmian kulturowych i cywilizacyjnych ${ }^{5}$.

${ }^{4}$ M. Ossowska, Ethos rycerski i jego odmiany, Wydawnictwo Naukowe PWN, Warszawa 2000, s. 7-8.

${ }^{5}$ W Tatrach przeprowadziłam wywiady z dwoma osobami, które można określić mianem ekspertów pracownikiem Tatrzańskiego Parku Narodowego (TPN) oraz ratownikiem Tatrzańskiego Ochotniczego Pogotowia Ratunkowego (TOPR), czyli ludźmi zajmującymi się zawodowo zagadnieniami związanymi z turystyka górską oraz dziesięciorgiem turystów. W próbie tej były 3 kobiety i 7 mężczyzn. Grupa „poznańska” składała się z sześciu osób - 4 kobiet i 2 mężczyzn. W sumie w badaniach wzięło udział 18 osób (w tym 2 ekspertów). Wszystkie badane osoby legitymowały się wykształceniem co najmniej 


\section{PRZEMIANY TURYSTYKI TATRZAŃSKIEJ W ŚWIETLE BADAŃ JAKOŚCIOWYCH}

Prawie wszyscy badani, z nielicznymi wyjątkami (K4, K6, M4) ${ }^{6}$, za znamienny rys turystyki tatrzańskiej uważaja bardzo dużą liczbę ludzi przybywających $\mathrm{w}$ Tatry $\mathrm{w}$ miesiącach letnich. Liczby robią wrażenie w okresie wakacyjnym zmierza w kierunku Morskiego Oka około 10000 osób dziennie (E1), w Zakopanem liczba miejsc noclegowych czterokrotnie przewyższa liczbę mieszkańców (120 000 na 30000 - E2). Respondenci wyrażaja swoje niezadowolenie $\mathrm{z}$ powodu tłoku na szlakach, konieczności rezygnacji z niektórych dróg ze względu na ich zbyt wielkie powodzenie wśród turystów. Rozmówcy są w gruncie rzeczy przekonani, że góry nie powinny być przeznaczone dla „mas”, lecz właściwie przed naporem tychże chronione ${ }^{7}$. Ratownik TOPR uważa, iż turystów jest na tyle dużo, że przydałoby się wprowadzenie odgórnych limitów i sztucznych ograniczeń (na przykład bramek wejściowych), ale zdaje sobie sprawę, iż byłoby to niemożliwe, gdyż - jak mówi - „ludzie by się zbuntowali” (E1). Wtóruje mu jedna z respondentek, również postulująca podjęcie działań instytucjonalnych na rzecz zmniejszenia ruchu turystycznego w Tatrach:

Może TPN wprowadzi jakieś ograniczenia, np. droższe bilety, obowiązkowe ubezpieczenia? Może nie będzie można dojechać do Morskiego Oka i część osób się wykruszy? Sa te projekty przeróbek Orlej Perci, już wprowadzono trasy w jedną stronę, bo wiadomo, że jest tak duży natłok na naszych szlakach, że trzeba sobie było jakoś z tym poradzić (K1).

Tylko jeden badany przyznał w wywiadzie, że również on sam należy do tego tłumu i poniekąd go tworzy:

Jest „,stonka”, ale z drugiej strony o mnie też tak można mówić. A każdy ma prawo, żeby tu przyjechać (M7).

Częściej można spotkać się z postawą dezaprobaty wobec wielkiej liczby turystów odwiedzających TPN, u których nie widać wrażliwości potrzebnej według reprezentantów grupy etosowej do uprawiania turystyki górskiej:

Za dużo jest teraz ludzi. To jest taki spęd. Bo to nie są tacy jak my, co przeżywaja, oni tylko zaliczaja (M2).

średnim, a większość wyższym (9 osób). Zróżnicowanie wieku badanych turystów (najmłodsza osoba miała w momencie badań 26 lat, najstarsza 80) pozwoliło na uzyskanie szerokiego spektrum doświadczanych i obserwowanych przemian w turystyce tatrzańskiej, jakie zaszły w ciagu ostatnich pięćdziesięciu lat.

${ }^{6}$ Każdemu z badanych przypisano określenie pojawiające się w tekście i przy cytowanych wypowiedziach. Oznaczenie składa się z litery wskazującej na płeć i odpowiedniego numeru porządkowego (K1-K7, M1-M9). Osobno oznaczeni zostali eksperci: E1 to ratownik TOPR, E2 - pracownik TPN.

W subiektywnym odczuciu respondentki (K4) obecnie chodzi po górach mniej osób, niż kiedy sama zaczynała przyjeżdżać w Tatry, gdy bardzo popularne były wycieczki szkolne czy z zakładów pracy: „,Dziś góry to przede wszystkim narty, latem jest bardzo mały procent [turystów górskich - A.D.]”.

${ }^{7}$ A. Ziemilski, Człowiek $w$ krajobrazie. Szkice z pogranicza socjologii, Sport i Turystyka, Warszawa 1976 , s. 128 . 
Jest to też wyraz tendencji do uznawania za turystów masowych wszystkich innych, lecz nie siebie, mimo iż współcześnie praktycznie każda podróżująca jednostka jest wprzęgnięta $\mathrm{w}$ machinę przemysłu turystycznego, choć część wzbrania się przed zaakceptowaniem tego faktu ${ }^{8}$.

Dosadnie o dewastacji atrakcyjnych miejsc, spowodowanej nieregulowanym rozwojem rynku turystycznego, wyraziła się Brigitte Bardot, która o kolejnych grupach odwiedzających odkryty przez nią kurort Saint Tropez mówiła, że „,sa prostaccy, ordynarni, niegrzeczni i chamscy”, co zmusza ją do ,,porzucenia tego miejsca zalanego falą ludzkiego śmiecia i pozostawienia go na pastwę intruzom" . Podobnie o Tatrach wyrażają się niekiedy ludzie przynależący do tatrzańskiej grupy etosowej, używając, jak już zostało powiedziane, chociażby pejoratywnych określeń względem turystów „niegodnych Tatr”. Ubolewaja przy tym nad degradacja przyrody, nazywana niekiedy ,zadeptywaniem gór" (K1), próbami rozbudowy infrastruktury w strefie górskiej (K2, M1) czy zawłaszczaniem przestrzeni przez rozwijające się prężnie u podnóża Tatr Zakopane.

Z przeprowadzonych wywiadów wynika, że w mniemaniu respondentów, Tatry niszczeją pod względem i fizycznym, i kulturowym, gdyż gros ludzi, którzy od lat regularnie przyjeżdżali eksplorować polskie Tatry, zaczęło w latach 90. XX w. wybierać miejscowości położone po drugiej stronie granicy, na Słowacji. Z początku była to radość, że można wreszcie bez przeszkód zobaczyć i zwiedzić południową stronę Tatr, znaną do tej pory najczęściej wyłącznie z literatury (K1, M1):

Bo o tych Tatrach, które kiedyś były duże i wspólne, kiedy ludzie chodzili bez ograniczeń terytorialnych, to się czytało. One [góry] były większe, te wyprawy organizowano według nas za granica, a dla nich [pierwszych turystów] to były jedne Tatry. Ci pierwsi eksploratorzy Tatr, którzy chodzili z przewodnikami góralskimi na kilkudniowe wyrypy do Kieżmarskiej, Pysznej [i poruszali się po całych Tatrach - A.D.] (K1).

Następnie Słowacja stała się miejscem, do którego ucieka się pochodzić po górach, ponieważ tam, z racji większego obszaru, wciąż można jeszcze znaleźć spokojniejsze, niezatłoczone, ciche tereny ${ }^{10}$. Tatry Słowackie są urokliwsze(M8), dziksze w porównaniu z polskimi (M9), ale jednocześnie lepiej przygotowane do obsługi ruchu turystycznego (K3). Jednak nie sa takim symbolem, jak Tatry

\footnotetext{
${ }^{8}$ Kazdy jest turysta, wywiad Joanny Matkowskiej z dr. Jakubem Isańskim, „n. p. m.: magazyn turystki górskiej”, listopad 2007, nr 11, s. 54-55. Redaktor przywołuje w rozmowie także pobłażliwe reakcje publiczności podczas projekcji filmu dokumentującego wspinaczkę Martyny Wojciechowskiej na Mount Everest w 2006 r., np. w trakcie scen, w których bohaterka piłowała paznokcie. J. Isański tłumaczy, że niezadowolenie audytorium i wyśmiewanie zachowań odbieranych jako nieodpowiednich w przestrzeni górskiej jest wynikiem wrażenia elitarności - „,prawdziwi podróżnicy nie zajmują się takimi drobiazgami na wyprawie, robią tak zwykli ludzie, dla których poznawanie świata nie jest autentycznym przeżyciem, tylko działaniem pokazowym” (choć sami łazienką zazwyczaj nie pogardzą). Analogiczną sytuację można obserwować i w polskich górach - grupa etosowa lekceważy nadmiernie dbających o wygląd i wygodę.

9 J. Urry, Spojrzenie turysty, Wydawnictwo Naukowe PWN, Warszawa 2007, s. 74.

${ }_{10}$ Respondenci poruszający się tylko po polskich Tatrach zaznaczają, że również tu wciąż można znaleźć mniej popularne drogi i miejsca, które pozwalają w spokoju „posiedzieć, pomyśleć i podziwiać widoki”, ale jest to na pewno zadanie dużo trudniejsze (K5, M4, M6).
} 
Polskie, w które jeździ się głównie z sentymentu i „,dla widoku” (K7). Tatry po polskiej stronie są też bardziej skondensowane, co powoduje, że przyciagaja ludzi lubiących mieć ,,wszystko w jednym”:

Wydaje mi się, że na Słowacji nie ma tyle ludzi... Są dłuższe szlaki... A tu masz taki koncentrat, wszędzie blisko, a doznań co niemiara. Wejścia sa ostre, ale wystarczą trzy, cztery godziny i jesteś na górze. I dreszczyk emocji jest. Ludzie mówią, że w tych Tatrach coś jest (K2).

Świadomość, że na mapie Polski jest takie miejsce, jak Tatry, że jest ono wspaniałe, zachwycające, symboliczne, istniało na długo, zanim rozpoczął się prawdziwy boom na Tatry obserwowany w ostatnim dwudziestoleciu. Dlaczego zatem dopiero dziś mówi się o masowości turystyki w tym rejonie i poddaje się ja przy tym fali krytyki? Adekwatna staje się trawestacja wypowiedzi Johna Urry'ego, która w odniesieniu do warunków polskich Tatr powinna brzmieć: teraz, kiedy tylu różnych ludzi może sobie pozwolić na przyjazd, to miejsce ulegnie zagładzie ${ }^{11}$.

Istotną cechą charakterystyczną współczesnej turystyki tatrzańskiej jest właśnie dostępność samych gór. Dostępność oznacza rozmaite zjawiska. Jest to i wspomniana dostępność w sensie finansowym - od 1989 r. coraz więcej ludzi stać na wyjazd i zorganizowanie pobytu w górach (K1, K2, K4), i dostępność fizyczna - wszędzie, przy dobrym planowaniu, można dotrzeć i zewsząd wrócić do punktu wyjścia w jeden dzień (K2, E1), lepsza infrastruktura - kwatery, miejsca noclegowe (K1, K3), poprawa komunikacji między Zakopanem a punktami wejścia na teren TPN (słynne „,busiki” - M1), lepszy dojazd do samego Zakopanego z innych stron Polski $(\mathrm{K} 3, \mathrm{~K} 5)^{12}$ i dostęp do informacji, na przykład za pośrednictwem stron internetowych albo telewizji, które podaja wiadomości o panujących $\mathrm{w}$ Tatrach warunkach pogodowych i pokazuja rozmaite obrazki z wybranych terenów (K3). Łatwiej również poruszać się w strefie górskiej, szlaki są dobrze utrzymane, opisane (M4, M5), w dolinach ustawiono przenośne toalety ułatwiające żywot turystom (K2). Postęp cywilizacyjny dotarł w ,dzikie ostępy”. Nie ma problemów z zaopatrzeniem, czy to w sprzęt turystyczny, czy w żywność, które wiele lat temu sprawiały, że wyjazd w Tatry wiązał się z dużymi wyrzeczeniami. Dziś już tylko wspomina się ,zawekowane w smalcu kotlety mielone" z lat 50. (K4), puszki i zapasy zbierane na długo przed wyjazdem w latach 70 . i 80., braki dotyczące podstawowych produktów (K1, K2). Podobnie rzecz miała się ze sprzętem. Worki służące za plecaki (M2), kij znaleziony w lesie (K6) i różnego rodzaju obuwie, w jakim poruszano się po górskich ścieżkach, z braku możliwości nabycia właściwego, stanowiły dodatkowe utrudnienie $\mathrm{w}$ uprawianiu turystyki górskiej w owych czasach. Obecnie brak odpowiedniego sprzętu jest wyłącznie kwestią wyboru,

11 Wypowiedź związana była ze zwiększeniem liczby lotów czarterowych do niegdyś ,,egzotycznego” kraju: „teraz, kiedy mogę sobie pozwolić, żeby tu przyjechać, to miejsce ulegnie zagładzie”. J. Urry, op. cit., s. 77.

${ }^{12}$ Choć jeden z respondentów stwierdza, że w tej materii nic się nie zmieniło od czasu, gdy był w Tatrach po raz ostatni w 1980 r.: „,Drogi nadal są w tak fatalnym stanie, że podróż nimi grozi uszkodzeniem samochodu, nie ma parkingów, a jak są, to ich ceny są horrendalne. Miasto i TPN »ciągnie kasę« od turystów, ale nie daje nic w zamian. Dobrze, że chociaż szlaki są dobrze utrzymane” (M5). 
a najczęściej zbyt małej wiedzy i niewłaściwego przygotowania do uprawiania turystyki tatrzańskiej, co zarzuca większości przyjezdnych w Tatry grupa turystów etosowych. „Teraz jak się jeździ, to się bierze kartę do bankomatu i wszystko można dostać na miejscu" - konstatuje respondentka z uśmiechem wracająca do wspomnień zabieranego z Poznania majonezu (K3). Dostrzegalne jest jednak rozrzewnienie, naturalne przy opisach początków ,,przygody z Tatrami”, które miały miejsce w czasach młodości części osób biorących udział w badaniu:

I jakoś ciekawe, że wraca się do tych wspomnień, kiedy było ciężko, a nie teraz, jak jest łatwo, kiedy wszystko jest. Chociaż w górach nigdy nie jest łatwo. Trzeba ten wysiłek wykonać (K2).

Rozmówcy są również wrażliwi na coraz bardziej komercyjny wymiar elementów turystyki tatrzańskiej i całej jej otoczki w postaci rozwoju Zakopanego i Gubałówki. Wprowadzenie zasad wolnego rynku wymusiło konkurencję i konieczność zabiegania o klientów, a turysta dziś to wszak w bardzo dużym stopniu właśnie klient, poszukujący odpowiednich usług. Musi gdzieś spać, coś zjeść, zabawić się, wydać przeznaczone na wakacje pieniądze. Miejscowa ludność czerpie dochody często wyłącznie $\mathrm{z}$ turystyki, nie jest więc dziwne, że stara się uczynić przede wszystkim miasto i obrzeża TPN jak najatrakcyjniejszymi. Komercja w Zakopanem to niekończące się ciagi straganów i sklepów z każdego rodzaju asortymentem, niezliczone punkty gastronomiczne w obrębie Krupówek, mnóstwo miejsc oferujących rozrywkę (na przykład symulatory: „,największa frajda na Krupówkach” - M9, lunety i letni tor saneczkowy na Gubałówce) i wszelkie usługi (na przykład rysowanie portretów i karykatur, tatuowanie henna czy nieśmiertelne fotografowanie z „,niedźwiedziem” i psem). Komercjalizacja w samych Tatrach to fasiągi konne do Morskiego Oka, prywatne busy dowożące turystów do miejsc, w których rozpoczynają się szlaki tatrzańskie, płatne parkingi u wylotów dolin, a także bilety wstępu do parku (E2).

Postępowanie naturalnych gospodarzy Zakopanego i Podtatrza - górali, budzi w przyjezdnych skrajne emocje. Społeczność góralska traktowana jest z jednej strony - jako element stały i potrzebny, ostoja polskiej tradycji i wiary katolickiej $^{13}$. Dzieje się tak nawet mimo świadomości, że wiele zwyczajów oraz wytworów kultury to tylko ,autentyzm inscenizowany w turystycznych dekoracjach" ${ }^{14}$. Scenografia złożona z tradycyjnych strojów, dorożek, regionalnych potraw, architektury drewnianej czy góralskiej muzyki ma urozmaicać turystom pobyt na Podhalu i sprawić, by poczuli się choć przez moment w zupełnie innym świecie niż na co dzień - bardziej powolnym, sielskim, gdzie

${ }^{13}$ Podhalański katolicyzm jest wciąż bardzo silny, choć inną sprawą jest, w jakim stopniu sprowadza się dziś głównie do obrzędowości. Współcześnie mieszkańcy Podhala coraz bardziej też oddalają się od przyrody, gdyż ona sama już nie jest w stanie przynieść im zysków. Zob. M. Grocholski, Aby góral byt człowiekiem, „Tygodnik Powszechny” z 17 sierpnia 2003 r., http://www2.tygodnik.com.pl/tp/nowy/ main01.php (16.04.2010).

14 D. MacCannell, Turysta, Muza, Warszawa 2005, s. 153-155. 
czas się zatrzymał, a ludzie żyją w zgodzie z Bogiem i natura. Świetnie oddaje taką tęsknotę wypowiedź miłośniczki tej, odrobinę wyśmiewanej, „góralszczyzny” i ,zakopianiny”:

Zakopane nie będzie miastem jak każde inne, nie są w stanie tam zrobić dobrego dojazdu, więc to na szczęście ogranicza jego rozwój. I to pozwala może nie na zrobienie z Zakopanego skansenu, ale na pokazywanie tradycji, która tam jest od lat. I myślę, że to w jakiś sposób powinno być chronione i że to jest najważniejsze (K3).

$\mathrm{Z}$ drugiej strony wiele osób, również tych niekoniecznie mających jakiekolwiek kontakty z Tatrami i samą społecznością góralska, postrzega ją poprzez negatywne stereotypy, w których górale sa kłótliwymi, walczącymi o każdy skrawek ziemi naciaggaczami, dążącymi wyłącznie do zysku (,,dla górali cena zawsze jest za niska" - M7, M4, M5). Cytowana powyżej rozmówczyni opowiada w dalszej części wywiadu:

Jak gdzieś jest trzech Polaków, to się na pewno pokłócą, to taka cecha narodowa. Słowacy potrafią się zorganizować, jakieś spółki założyć, wyciąi pobudować, a polski góral to sam by postawił jakieś słupki, jeszcze sam by wwoził tych turystów, ale tylko na swoją górkę i żeby dochód był tylko dla niego. Ale może w tym też jest urok, że my mamy to Zakopane z góralami walczącymi, a tamci nie mają (K3).

Dodaje również, że chęć zarobku sprawia, iż podtatrzańscy gospodarze nie cofną się nawet przed oszukiwaniem przybywających do nich gości i turystów:

Oscypki nie sąjuż z mleka owiec, tylko z mleka krowiego. Przeciętny turysta tego smaku nie rozpozna, jest mu wszystko jedno. Świadomość jest jednak, że coś jest nie tak (K3) ${ }^{15}$.

W wir komercyjnych przemian wciągnięto także schroniska górskie. Sa jak dobrze zaopatrzone sklepy i restauracje, co pozwala nie martwić się o zapas jedzenia i picia na szlaku (K4). W niektórych przypadkach turyści nie muszą się też troszczyć na przykład o odzież przeciwdeszczową czy leki przeciwbólowe, ponieważ i takimi rzeczami dysponują dziś schroniska i w razie konieczności zawsze można je nabyć. Oczywiście taki status dzisiejszych schronisk powoduje zwiększenie wygody turystów w przestrzeni tatrzańskiej i jest zjawiskiem w ogólnym rozrachunku pozytywnym (zawsze i każdemu może przytrafić się, że zabraknie mu wody lub podrze kurtkę), ale też usprawiedliwia beztroskę i zabija pewne ,tatrzańskie ceremoniały”. Nie spotyka się już chociażby osób przygotowujących posiłki gdzieś na szlaku lub we wspólnej jadalni (K1, K2, M1):

Kiedyś to tak lubiliśmy właśnie siadać gdzieś na szczycie i wyciągać wszystkie wiktuały i robić popas, otwierać puszki. Ale to też było sympatyczne, znowu pewien rytuał. [...] Kiedyś się przecież nie kupowało herbaty w schronisku. Nosiło się kubek i prosiło o wrzątek. Prosiło się, wtedy był bezpłatny. Zmiana czasu (K1).

\footnotetext{
${ }^{15}$ Rejestracja oscypka jako produktu regionalnego chronionego prawem Unii Europejskiej narzuciła zachowywanie określonych norm przy produkcji tego sera, o co usilnie zabiegała społeczność polskich górali. Zob. //www.minrol.gov.pl/index.php?/pol/Jakosc-zywnosci/Produkty-regionalne-i-tradycyjne/ Lista-produktow-tradycyjnych/woj.-slaskie/Oscypek-oszczypek.
} 
Gorąca woda, która częstowano turystów w schronisku była jakimś symbolem wspólnoty, oznaką gościnności ze strony dzierżawców schronisk. Wprowadzenie opłaty za nią oznacza zerwanie z tradycją i - szczególnie w odczuciu turystów od lat chodzących po Tatrach - chęć zarabiania na wszystkim, na czym się tylko da. Obecnie zresztą schroniska w Tatrach funkcjonuja na zasadzie hoteli - można w nich zanocować po uprzedniej rezerwacji łóżka w schroniskowym pokoju lub gdy pozostały wolne miejsca. Nawet tak zwana ,,podłoga” w salach jadalnych jest w najpopularniejszych schroniskach reglamentowana i podlega rezerwacji oraz opłatom (,,co wcześniej nie było praktykowane" - M1) ${ }^{16}$.

Jednym z najbardziej jaskrawych przykładów uzależniania gór od mechanizmów rynkowych są najnowsze działania w sferze ochrony przyrody. Brak dostatecznych funduszy na ten cel powoduje konieczność pozyskiwania przez TPN sponsorów. Rezultatem takich działań jest akcja „Milka-Razem dla Tatr” organizowana przez właściciela marki Milka, firmę Kraft Foods Polska SA. Zaproponowano tutaj wsparcie finansowe na łączną kwotę miliona złotych dla trzech z sześciu wybranych symboli tatrzańskich - Giewontu, kozicy, krokusa, Morskiego Oka, niedźwiedzia brunatnego lub świstaka. Wyboru dokonać maja internauci, głosując na dany symbol poprzez stronę ,razemdlatatr.pl” (udostępniona przez portal Onet.pl, obok „Gazety Wyborczej” i telewizji TVN, jednego z partnerów akcji $)^{17}$. Można się oczywiście zastanawiać, jak traktowane maja być trzy pozostałe $\mathrm{z}$ wytypowanych do swoistego konkursu symbole, które nie znajda uznania w oczach internautów, a także inne, „mniej symboliczne” miejsca czy elementy fauny i flory tatrzańskiej. Najistotniejszym wnioskiem nasuwającym się przy obserwacji tego typu akcji jest fakt, że sukces w kwestii ochrony środowiska naturalnego zależy dziś od dużych nakładów finansowych, które zapewnić może współpraca z koncernami. Niezależnie od efektów sponsoringu jest on głównie instrumentem promocji marki. Nagłośnienie medialne, choć wpływa na odbiór Tatr jako ogólnopolskiego dobra, które w myśl idei kampanii trzeba wspólnie chronić, to jednak jego nadrzędnym celem jest wykreowanie pozytywnych skojarzeń z samą marką słodyczy Milka, co przekłada się na zwiększenie sprzedaży i wzrost zysków. Wymiar akcji jest zatem, mimo wspierania niewatpliwie słusznej sprawy, przede wszystkim komercyjny.

${ }^{16}$ T. Zwijacz Kozica, Schroniska nie sa z gumy, „Tatry” 2009, jesień, nr 4 (30), s. 8-9. Takie postępowanie, mimo że również jest przejawem komercjalizacji, ma jednak swoje głębsze uzasadnienie. Schronisko, zgodnie ze swoją nazwą, służy bowiem schronieniem ludziom znajdującym się na terenie gór, gdy pragną odpocząć lub gdy nagłe załamanie pogody uniemożliwi dalszą wędrówkę. Jednakże przy takim natłoku turystów fizyczną niemożliwością jest przyjęcie wszystkich pod dach schroniska, zwłaszcza w momencie gdy sytuacja tego nie wymaga, a ,,awaria staje się reguła”. Wielu turystów poszukuje tam po prostu zwykłego noclegu, gdyż na przykład spanie w „Murowańcu” na Hali Gąsienicowej jest sporym ułatwieniem, gdy planuje się przejście Orlej Perci. Nie zważają jednocześnie na konieczność rezerwacji, dlatego że wedle pokutującej romantycznej wizji, schronisko przyjmie „każdego strudzonego wędrowca”. W podobny sposób myślą ludzie przychodzący po zmroku do wysokogórskiego schroniska z małymi dziećmi, co również stało się nagminne (autor artykułu potwierdza zatem obserwowaną przez respondentów tendencję zabierania maluchów na górskie wycieczki i również ja potępia).

${ }_{17}$ Akcję zaplanowano na maj i czerwiec 2010 r., a jej ostatni akcent stanowi Letni Festiwal Milki odbywający się w Zakopanem, które również patronuje akcji. Zob. http://razemdlatatr.pl/o_akcji.html (5.05.2010). 
Postęp cywilizacyjny - jak z żalem odnotowują respondenci - zabija romantyczną ideę chodzenia po Tatrach, u której podstaw leży niezapośredniczony, czysty kontakt z krajobrazem i wszechogarniająca przyroda. Trudno jednak wyobrazić sobie, by Tatry stały się „muzeum dawnych czasów”, by nie korzystano z udogodnień technicznych, na przykład telefonów komórkowych czy profesjonalnego ekwipunku turystycznego. Byłoby to, po pierwsze, niemożliwe, po drugie - zupełnie bezcelowe. John Urry podkreśla poza tym, że „,nawet turyści pamiętający spokojniejsze czasy chętnie korzystają z usług, które w pionierskim okresie słabego ruchu turystycznego były nieosiagalne", zatem również czerpią z turystyki masowej ${ }^{18}$. Nocowanie na sianie, w bacówce pozbawionej dostępu do prądu i bieżącej wody, co było normalne w latach 50 . minionego stulecia (K4, M2), w XXI w. można by potraktować jako chęć zafundowania sobie dodatkowych wrażeń (pogoń za autentycznością), a najpewniej jako anachronizm. Podobnie korzystanie z przestarzałego sprzętu uznano by raczej za lekkomyślność niż wyraz przywiązania do etosu, w którym jednymi z najistotniejszych wartości sa rozwaga i troska o bezpieczeństwo, czemu używanie na przykład pionierek czy trampek przeczy.

Największy żal niektórych rozmówców, co wypada po raz kolejny powtórzyć, spowodowany jest jednak utratą atmosfery wzajemnej przychylności i wspólnotowości. Zanik wynika $\mathrm{z}$ bardzo dużej heterogeniczności turystów w Tatrach i zróżnicowania ich poglądów na turystykę górską, a także same Tatry. Zanikowi ulega swoista wspólnota zapatrywań i pasji, która potrafi połączyć nieznajomych ludzi. Dziś jest to wyróżnik nowoplemion - form zróżnicowania społeczno-kulturowego, którego przejawy odnaleźć można w dynamicznie zmieniającym się społeczeństwie masowym (Michel Maffesoli). Marian Golka pojmuje je jako odległe przestrzennie zbiorowości, których poczucie wspólnoty i tożsamości powstaje nie w wyniku wspólnego wychowania i przebywania, lecz wskutek wspólnych zainteresowań, pomysłu na spędzanie wolnego czasu, zbieżnych ideałów czy poglądów.

Jakie są cechy nowoplemion? Ich członkowie nie spotykają się na co dzień, lecz okazjonalnie, maja poczucie wspólnoty kulturowej i integrują się niezależnie od różnic i barier statusowych (zawodu, wykształcenia, wieku). Komunikacja pomiędzy członkami jest możliwa za pośrednictwem nowoczesnych mediów, takich jak Internet czy telefonia komórkowa ${ }^{19}$. Grupę etosowa skupioną wokół Tatr i turystyki tatrzańskiej można by nazwać właśnie takim nowoplemieniem. Nie wszystkie z powyższych ustaleń odnoszą się w całości do turystów tatrzańskich odznaczających się etosem. Po pierwsze - sam etos, tak jak został zdefiniowany w punkcie drugim artykułu, jest pojęciem szerszym, zawierającym nakazy i zakazy normatywne kreowane na podstawie nadbudowy ideologicznej, hierarchii wartości, motywów i celów postępowania.

Po drugie - raczej trudno $\mathrm{w}$ odniesieniu do przyjeżdżających $\mathrm{w}$ Tatry turystów mówić o komunikacji, dzięki której mogliby oni spotykać się „,okazjonalnie, ale nie przypadkowo". Turystów w Tatrach jest obecnie tak wielu, że

\footnotetext{
18 J. Urry, op. cit., s. 74.

19 M. Golka, Socjologia kultury, Scholar, Warszawa 2007, s. 200-201. Autor przyznaje, że zarówno studia teoretyczne, jak i badania empiryczne nad nowoplemionami są jeszcze słabo rozwinięte.
} 
nawet wśród tych etosowych, których liczebność jest oczywiście dużo mniejsza, panuje anonimowość, a spotkania w przestrzeni tatrzańskiej nie są wynikiem wcześniejszych porozumień. Marian Golka jako przykłady nowoplemion podaje alterglobalistów czy miłośników starych motocykli, którzy spotykają się przy okazji organizowanych zlotów czy akcji. W wypadku wypadów w Tatry takie zdarzenia nie mają miejsca, także spotkania „,etosowców” mają jednak charakter przypadkowy (choć niektórzy respondenci zwracają uwagę, że ,,zejście się” w górach ,,prawdziwych turystów" możliwe i najbardziej prawdopodobne jest poza sezonem, we wrześniu czy październiku - K3, K5, M4). Jednakże kategoria nowoplemion może być użyteczna dla dzisiejszego odbiorcy fenomenu tatrzańskiego jako pewne przekształcenie etosu lub jego możliwa przyszła postać, gdy etos ze swym twardym rdzeniem zacznie zanikać. A to powolne zanikanie obserwowane jest przez badanych już teraz. Twierdzą, że olbrzymi wybór modeli spędzania wolnego czasu sprawia, iż ludzie coraz rzadziej decydują się na aktywność wymagająca dużego wysiłku, przedkładając nad nią wygodę i relaks, często utożsamiany z bezczynnością (K4, M2). Mówią także, że nie jest łatwo przekazywać czy kontynuować rodzinne tradycje, ponieważ chodzenie po Tatrach przestaje być atrakcyjne, gdy realna jest opcja wyjazdu na przykład w Alpy (K3, K5).

Jest to także doskonały przykład idealizowania czasów, na które przypada młodość respondentów lub które inni znają z literatury czy przekazów rodzinnych. Dla wszystkich dziś romantyczna i pozytywistyczna turystyka tatrzańska jest mitem, prawie że arkadyjskim. Do tej pory odbiór Tatr determinuje w pewnym stopniu programowo emocjonalny i przesycony egzaltacja oraz metafizyką stosunek do gór i górskich widoków. Poza tym zawsze zmiany i nowe formy działania w obojętnie jakich sferach są przyjmowane w najlepszym razie ze sceptycyzmem i niechęcią. Wystarczy wspomnieć Stanisława Zielińskiego roztrząsającego sprawę podejścia do turystyki w Tatrach z punktu widzenia „,starych taterników”, rozpoczynających karierę jeszcze przed pierwszą wojna światową, którzy dostrzegali, że pokolenie turystów w latach 30 . XX w., jest inne niż ich własne, i zadawali pytania o pokorę wobec gór:

Gdzież podział się ów lęk przed górami? Czyżby następne pokolenia były od niego wolne? Mówiono: „To bardzo dobrze”. Mówiono również: „To bardzo źle”. Jedni i drudzy mieli sporo racji ${ }^{20}$.

Podobne reakcje względem fali nowych, lecz teraz nie taterników, a turystów można obserwować i dzisiaj, zwłaszcza wśród ,etosowców”. Zapytani wprost o etos tatrzański ${ }^{21}$ odpowiadają:

W ogólnej liczbie turystów tych osób wyznających pewien etos będzie mniej. Zostanie stała liczba, bo turystów jest w sumie coraz więcej, a etos się przenosi pokoleniowo, a tylko część osób przywożonych teraz w Tatry jako dzieci w przyszłości ,zaskoczy”. Albo i nie. [...] Etos się z powietrza nie weźmie (M1).

\footnotetext{
20 S. Zieliński, W strone Pysznej, Zysk i S-ka Wydawnictwo, Poznań 2008, s. 252.

${ }^{21}$ Termin ,etos turystów tatrzańskich” był przez rozmówców, którym zadano o niego bezpośrednie pytanie, rozumiany bez nieścisłości i intuicyjnie prawidłowo.
} 
Podejrzewam, że ci ludzie, którzy ,załapali bakcyla”, to w jakiś sposób przekazuja to swoim dzieciom, jak rozmawiamy ze znajomymi, którzy gdzieś tam jeżdżą, to się okazuje, że młodzi to kontynuuja, choć nie jest to reguła. Niektórzy nie kontynuuja wysiłku, może pojechali w zbyt młodym wieku albo zrobili sobie jakąś krzywdę? (K1)

Turystyka nie zmienia się aż tak bardzo - teraz jest po prostu łatwiej, nie ma aż tylu wyrzeczeń. Na pewno uległa umasowieniu, ludzi jest bardzo dużo w sezonie urlopowym, ale zawsze pozostaną ci charakteryzujący się etosem (K5).

Starsi turyści przekazuja etos, ale wśród młodych jest rzadko spotykane. Przez komercjalizacje góry zatracają swoją moc, którą miały, gdy było więcej etosowych turystów (K7).

Etos na pewno odchodzi, nie jest już tak istotny, jak był wcześniej (E2).

Konstrukt, jakim jest etos, nie pomaga dziś w uprawianiu turystyki, trudno przebić się z raczej niepopularnymi wartościami do ogólnej świadomości. Fakt, że coraz mniej osób reprezentuje te same co grupa etosowa poglądy i wartości ujawniające się w czynnym uprawianiu turystyki, przez co owa społeczność się kurczy i traci na znaczeniu, napawa smutkiem i obawa.

\section{ETOS KONTRA KOMERCJALIZACJA - PODSUMOWANIE}

Komercjalizacja i umasowienie turystyki tatrzańskiej znacząco wpłynęły na jej charakter. Szlaki górskie we wszystkich sferach przypominają, biorąc pod uwagę liczbę osób, raczej trakty spacerowe, gdyż tłok na Krupówkach i drodze do Morskiego Oka jest porównywalny. Wyjazd w góry dla wielu osób niczym się nie różni od wypadu gdziekolwiek indziej. Zakopane jest dziś przecież miastem jak każde inne, a możliwość pospacerowania, niekiedy z dodatkową porcja adrenaliny, po Tatrach to świetny dodatek do wczasów. Czy uzasadnione jest więc twierdzenie, że etos turysty tatrzańskiego upada?

Nie sposób jednoznacznie odpowiedzieć na to pytanie, zważywszy chociażby na możliwość dość swobodnego dotarcia do przedstawicieli grupy etosowej, co miało miejsce przy okazji badań prowadzonych na potrzeby niniejszej pracy. Z kolei obserwacje i refleksje rozmówców ukazują symptomy świadczące o zanikaniu etosu. Taki stan rzeczy, najczęściej źle oceniany (w szczególności przez osoby $\mathrm{z}$ długoletnim stażem tatrzańskim) tłumaczy się wpływem nowoczesnej kultury, która przynosi odmienne wzorce, nowe mody, daje wachlarz wielu możliwości zagospodarowania czasu wolnego od pracy. Zdania na temat kondycji dzisiejszej turystyki tatrzańskiej, jak i jej przyszłości, sa jednak podzielone. Nie ma nawet jednomyślności w kwestii liczby turystów mających przyjeżdżać rokrocznie w Tatry, choć statystyki pokazują, że ta liczba, chociaż powoli, stale wzrasta. Niektórzy respondenci dowodzą, że turyści będą mniej chętnie zaglądać w Tatry, ponieważ te traca na atrakcyjności $\mathrm{w}$ zestawieniu z alternatywą wyjazdu na trekking w góry Azji czy Ameryki Południowej lub choćby Alpy (K3, K4). Pojawia się argument dotyczący wygody. Dzisiejsze społeczeństwo postrzegane jest jako niechętne aktywnemu wypoczynkowi, w związku z tym rozmówcy uważają, że ludzie nie będą chcieli 
przyjeżdżać w góry, których zdobywanie wymaga fizycznego wysiłku (,ludzie idą nad Morskie Oko, bo połowa może końmi wjechać” - K2, „ludzie wola pojechać nad ciepłe wody” - M2). Dlatego „,siermiężne Tatry”, w których nie ma możliwości wjechania nigdzie poza Kasprowym Wierchem, nie spełniaja oczekiwań przeciętnego turysty, którego już nie zachwyca historia „dziewiętnastowiecznych wypraw w Tatry Zachodnie":

Już przeszliśmy ten okres chodzenia po dwanaście godzin [dziennie], każdy wolałby wjechać i zobaczyć. W Alpach też nie chodzimy pieszo, tylko wszędzie wjeżdżamy. W Tatrach nie ma możliwości. A ludzie stają się wygodniejsi. [...] Zresztą moje dzieci, mimo że chciałam im zaszczepić Tatry, to tu nie przyjeżdżają. Na narty w Alpy, bo tu nie ma warunków, a jak jadą zima, to latem gdzieś indziej, żeby się nie powtarzać. Chca oglądać coraz więcej (K4).

Badani przynależący do grupy etosowej mówią też, że przede wszystkim przestaną przyjeżdżać turyści, tacy jak oni, dla których przebywanie w przestrzeni tatrzańskiej i piesza turystyka górska (,nie taternicka, górska” - K4, M1) jest kwintesencja pobytu w Tatrach. Większość przypuszcza jednak, że ogólna liczba turystów w polskich Tatrach będzie się sukcesywnie powiększać (K1, M1, M4, M6), co również będzie miało ujemny wpływ na jakość turystyki i stan ekosystemu (,,zwierzęta się niby zaadaptowały do nowych warunków, ale czasem turystów jest tak dużo, że te nie mogą się przedostać na drugą stronę drogi" - E1):

Przeraża mnie komercjalizacja i to, że przyjeżdża tyle ludzi. Ale na pewno coraz większa liczba będzie przyjeżdżała nie tylko dla zakopiańskiego szpanu, ale też dla gór i będzie jeszcze większy tłok. [...] Trochę się obawiam, że zadepczemy nasze Taterki (K1).

Mam taką cichą nadzieję, że „herbatnikom” się znudzi, że byli z dziećmi i one już tego nie pociągną. Bo jak tak dalej pójdzie, to Tatry zostaną zadeptane i będzie trzeba uciekać, ale nie wiem dokąd. Nie znam innego pasma górskiego, które byłoby właśnie takie jak Tatry. Nie chciałbym uciekać, wolałbym, żeby to oni [turyści przypadkowi] sobie poszli! (M1).

Analizując strukturę społeczna, można powiedzieć, że nie zmienia się na pozór aż tak wiele - nadal większość osób chodzących po Tatrach reprezentuje najlepiej wykształcona warstwę polskiego społeczeństwa ${ }^{22}$. Ale o ile turystyka tatrzańska ma niewątpliwie inteligencki rodowód, o tyle nie do końca uprawnione jest mówienie o jej inteligenckim charakterze obecnie. Dzieje się tak za względu na bardzo różne możliwości wyższego wykształcenia oraz już wspominaną coraz większą, a właściwie węższą specjalizację (już od poziomu szkoły średniej), która sprawia, że problematyczne staje się wyłonienie jakiegoś kanonu wiedzy ogólnej, wspólnej dla szeroko pojętej klasy inteligencji, wyróżnianej często w charakterystyce struktury klasowej społeczeństwa w Polsce.

\footnotetext{
${ }^{22}$ Jeśli zsumuje się odsetek osób z wyższym wykształceniem z odsetkiem studentów, którzy formalnie legitymują się wykształceniem średnim, ich liczba wyniesie 77,9\%. Zob. Z. Ładygin, B. Chovancová (red.), Monitoring ruchu turystycznego w Tatrach 5-7 sierpnia 2004 r., Wydawnictwa Tatrzańskiego Parku Narodowego, Zakopane 2005, s. 71-72.
} 
Dziś jednak utożsamianie wszystkich osób posiadających wyższe wykształcenie $\mathrm{z}$ pojmowana $\mathrm{w}$ zwyczajowy sposób inteligencja jest niewłaściwe. Ten tradycyjny wyróżnik traci zatem na znaczeniu w wyniku transformacji ustrojowej oraz przemian makrostrukturalnych późnej nowoczesności (ponowoczesności), gdy przedefiniowaniu ulega pojęcie elity intelektualnej, postrzeganej nawet $\mathrm{w}$ latach panowania socrealizmu jako grupy nadającej ton życiu społecznemu ${ }^{23}$. Skutki zmian widoczne są zatem również $\mathrm{w}$ stylach życia i spędzania wolnego czasu, w których przodowała inteligencja, a więc także w etosowym sposobie uprawiania turystyki tatrzańskiej.

Przewidywanie, jak wyglądać będzie oblicze turystyki tatrzańskiej w kolejnych latach jej rozwoju - gdyż to, że mamy do czynienia z postępem, przynajmniej ilościowym, jest raczej oczywiste - bynajmniej nie jest łatwe. Widoczne sa tendencje komercjalizacyjne: zawłaszczanie przestrzeni $\mathrm{w}$ bezpośrednim otoczeniu parku narodowego (mnóstwo straganów, lokali gastronomicznych, punktów usługowych), polepszanie na terenie samego TPN infrastruktury turystycznej poprzez ingerencję w środowisko naturalne (na przykład propozycja budowy elektrowni wodnej w Dolinie Roztoki). Również oferowane przez górali przejażdżki bryczkami czy wozami konnymi nie stanowią już o uroku i miejscowym folklorze, lecz stały się elementem machiny turystycznej, o czym świadczy opisywany drastyczny przypadek śmierci konia pociągowego. Nie można jednoznacznie zakwalifikować zjawisk skorelowanych z wzrastająca ogólnie popularnością Tatr jako miejsca destynacji wakacyjnego wypoczynku do konsekwencji negatywnych. Respondenci zwracają uwagę, że dzięki powszechnemu dostępowi do mass mediów i dość częstej obecności w nich Tatr, zwiększa się świadomość chociażby konieczności posiadania przystosowanego do warunków górskich sprzętu, przy czym wiedza jest najczęściej powierzchowna i nieusystematyzowana. W dodatku postęp w dziedzinie przygotowania technicznego jest zauważalny, ale nie powszechny, gdyż osoby odpowiednio ubrane i wyekwipowane nadal przykuwają wzrok i wyróżniają się z tłumu. Nie zostały wyeliminowane z krajobrazu tatrzańskiego klapki, buty na obcasie czy torby na ramię, wiele zachowań budzi zdziwienie bądź niezadowolenie u doświadczonych turystów lub ekspertów - ratowników TOPR, pracowników TPN (chociażby brak znajomości nazwy miejsc, do których odbywa się wycieczki). Ogólne zasady bezpiecznej turystyki górskiej, w której założeniach jest szacunek dla środowiska naturalnego, ale też dla innych ludzi, nie trafiaja, jak widać, do bardzo w tym momencie szerokiego kręgu turystów.

Jak wynika z opinii rozmówców, dziś już rzadko widać fascynację Tatrami, która skłaniałaby do poszerzania owej wiedzy i poznawania historii kultury turystyki tatrzańskiej, a także zagłębiania się w etos. Nie powstaje nowa literatura tatrzańska, która dotyczyłaby dzisiejszej turystyki i kultury turystycznej w Tatrach. A ludzi mimo wszystko przybywa. Powodem dobrowolnego przyjazdu w Tatry jest fakt, że wciąż są one uznawane za najpiękniejszy rejon Polski, najbardziej niecodzienny, w którym przebywanie dostarcza wielu

${ }^{23}$ Zob. fragmenty książki A. Radziewicza-Winnickiego Społeczeństwo w trakcie zmiany. Rozważania z zakresu pedagogiki społecznej $i$ socjologii transformacji, Gdańskie Wydawnictwo Psychologiczne, Gdańsk 2004, http://czytelnia.onet.pl/0,1177944,do_czytania.html (19.04.2010). 
wrażeń. Ruch w polskich Tatrach byłby też pewnie zdecydowanie mniejszy, gdyby nie istnienie Zakopanego $\mathrm{u}$ ich podnóża, w takiej formie, w jakiej jest znane. Miasto wraz ze swymi atrakcjami sprawia, że chodzenie po górach przestało być tu najważniejszą formą zagospodarowania wolnego czasu podczas wakacyjnego pobytu. Co prawda, ludzie przyjeżdżający na wypoczynek do Zakopanego nadal wchodzą na teren parku, szlaki, w szczególności te dolinne, są zapełnione o każdej porze dnia i praktycznie przy każdej pogodzie. Dlatego we wszystkich analizach obecnego stanu turystyki tatrzańskiej nacisk kładzie się głównie na olbrzymią w relacji do wielkości terenu Tatrzańskiego Parku Narodowego liczbę turystów, która - zdaniem obserwatorów i prawie wszystkich respondentów i ekspertów biorących udział w badaniach przeprowadzanych na potrzeby tej pracy - skutkuje pogorszeniem się jakości turystyki tatrzańskiej. Masowość, bezrefleksyjność, zaliczanie, komercja - to skojarzenia ze współczesną turystyką uprawianą w Tatrach. Etos, nawet wśród samych osób należących do grupy go kultywującej, schodzi powoli na dalszy plan, a że nie ma komu go przekazywać, prawdopodobnie zaniknie.

mgr Anna Datko

Uniwersytet im. Adama Mickiewicza w Poznaniu

datko@amu.edu.pl

\section{CONTEMPORARY TATRA TOURISM AND ITS ETHOS}

\section{Summary}

The paper touches upon some origins of contemporary Tatra tourism and its ethos in the ever-changing modern world. It provides a theoretical outline of the concept of 'ethos' regarding touristic exploration of the Tatra Mountains and the characteristics of the elements that have determined tourism in the last twenty years (based on qualitative research). The main features of tourism in the Tatra that are now being observed are popularisation, commercialisation, decline of some traditional ways of thinking about mountaineering and practicing it as well as changes within the ethos and its peculiar community (or rather disappearance of them both). In this context very important are also some environmental issues, such as devastation of the natural ecosystem and expansion of urban practices deeper and deeper into the Tatra National Park. Last but not least one other issue touched upon in the paper is the 'touristic' knowledge and skills that are now very rare among the tourist who visit the Tatra, which also leads to the decline of the ethos. 